DOI https://doi.org/10.18551/rjoas.2018-02.12

\title{
THE EFFECT OF QUALITY OF WORK-LIFE AND MOTIVATION ON EMPLOYEE ENGAGEMENT WITH JOB SATISFACTION AS AN INTERVENING VARIABLE
}

\author{
Endayani Fatmasari* \\ Master's Program of Business Administration, Faculty of Administrative Science, \\ University of Brawijaya, Indonesia \\ Musadieq Mochammad Al, Afrianty Tri Wulida \\ Faculty of Administrative Science, University of Brawijaya, Indonesia \\ *E-mail: endayanifatma@gmail.com
}

\begin{abstract}
This study aims to analyze the effect of quality of work-life and work motivation on employee engagement and job satisfaction as an intervening variable. Quality of work-life is the foundation which determines the level of satisfaction and engagement in an organization. Explanatory research with a quantitative approach was conducted on a private university in Malang with 74 respondents. This study uses Path Analysis to examine research data. It is found that the motivation provided by the university towards the lecturer, such as job security, reward, and spirit, can increase the satisfaction and engagement. Similarly for job satisfaction, the relationship between colleagues and a comfortable working environment can create lecturers' engagement in the institution.
\end{abstract}

\section{KEY WORDS}

Quality, work motivation, job satisfaction, employee, engagement.

Strategy to achieve the advantage of human resources by optimizing the role of each human resource (HR) so as to encourage morale and compete and create a good quality of work life and able to increase motivation. This will be useful as a way to retain employees, when the management of quality of work life aims to improve competitiveness for the company. Quality of work life is the implementation of Human Resource Management (HRM) policies and practices designed to improve organizational performance and employee welfare (Stone, 2005). Better quality of work life leads to an increase in employee morale, minimizing friction and reducing labor turnover. Therefore, the assumed that when the right atmosphere is provided to employees, they can provide effective and efficient performance (Arif \& Ilyas, 2013). Quality of work life has a perspective of managerial approach that emphasizes on factors that effect work motivation and job satisfaction. If the employee feels that the needs of the workplace are available or exceed expectations, then they feel a better level of quality of work life, which will increase their level of job satisfaction. In addition, Quality of Work Life not only affects job satisfaction but also other forms of life satisfaction that is family relations, recreation and social aspects (Crohan et al., 1989; Schmitt and Mellon, 1980; Sirgy et al., 2001; in Lee et al., 2015). When viewed the impact on motivation, which Ivancevich (2010), explained that motivation can provide energy, channel, and a person's behavior to achieve company goals. Motivation relates to the strength and direction of behavior and the factors that influence people to behave in a certain way (Armstrong, 2010). Therefore, motivation needs to be considered by a leader. If the employee motivation is high it will have an impact on the increase of job satisfaction.

Ference (1982) argues that employee perceptions of the quality of work life that can satisfy their needs can significantly improve job satisfaction. In addition, the higher the level of job satisfaction will cause employees engaged in their workplace (Park \& Gursoy, 2012). Employee engagement is defined as a general level of commitment and employee engagement with company values. When employees are involved, they will realize their responsibilities and motivate colleagues to achieve organizational goals (Anitha, 2014). Research conducted by Kanten \& Sadullah (2012) which explains the influence between the 
quality of work life to employee engagement and the results show the difference in the level of engagement in the employees who depend on the motivation of each individual. When an employee is engaged in a job, it affects the employee's psychological character, such as selfconfidence and optimism, will encourage employees further and this will encourage satisfaction and result in low employee turnover intentions.

In this research found research gap from previous research that is, research by Günay \& Boylu (2014) shows that quality of work life a negative effect on job satisfaction. The study shows that there is a decrease in the level of quality of work life among academics, but job satisfaction increases. Research conducted by Lee, et al. (2015) revealed that each attribute of quality of work life has a different impact on job satisfaction. The results of the study explain the quality of work life does not fully have a positive and significant impact on job satisfaction. Therefore, it is necessary to conduct further research on the quality of work life on job satisfaction. In addition, there are also some phenomena that occur such as the workload of lecturers is very high so it needs to be considered the quality of life work. This refers to "Tri Dharma" of the university that includes education \& teaching, research, community service, and supporting activities such as active in the committee. In addition, there are additional teaching hours for regular class students in the afternoon (extension program) increase the workload of lecturers.

Currently, the competition of universities in Indonesia, especially in Malang is increasing.. They are competing to get quality inputs that can compete in national and international level. Various methods have been done by universities to achieve the goals. One of them is to improve the quality of work life and motivation of lecturers in universities. If the lecturers have the high motivation they will show their totality and loyalty to the institution, but if they do not have motivation, then the lecturers tend to show less optimal performance. This situation will greatly affect the quality of the universities. From the explanation of the phenomenon and research gap in this study, the purpose of this study is to analyze the quality of work life and motivation to employee engagement with job satisfaction as an intervening variable at lecturers of the Merdeka University of Malang.

\section{LITERATURE REVIEW}

Quality of Work Life. A condition of the outcome of an interaction between individuals and jobs, can make employees more productive and lead to job satisfaction is a form of quality of work life. Cascio (2006) defines that quality of work life is the employee's perception of their mental and physical well-being in the workplace. Furthermore, Nawawi (2001) argues the quality of working life is program that includes method to improve the quality of life by creating a better job. There are two ways to understand the definition of Quality of Work Life (QWL) according to Cascio (2006). The first, that quality of work life is a collection of situation and practices of organizational goals, such as promotional policy, democratic work supervision systems, employee engagement, and security works. The second is the quality of work life is viewed with the perception that the employees are safe, very satisfied, and can grow up and develop as human beings. Both of these views based of emphasize the relationship between the quality of work life with the available of employee needs.

Quality of Work Life means the impotant of reward to employee in their working environment can change the work climate so that the organization can technically bring employees to a better quality of work life. Efforts in improving the quality of work life according to Cascio (2006) are: (1) the leader must be able to protect, (2) the openness and trust between colleagues, (3) sharing information between top management with staff, (4) change to achieve goals. In this study, the indicators used to measure Quality of work life refers to research conducted by Lee et al. (2015), such as health and safety needs, economic needs, self- actualization needs and self-actualization and esteem needs, social and knowledge needs.

H1: Quality of Work Life has a significant effect on Job Satisfaction.

Work Motivation. The motivation of work is a condition that encourages others to perform tasks in accordance with their functions within the organization, have the ability to 
act and respond in achieving the goals and objectives of the organization (Bangun, 2012; Siagian, 2004). The purpose of providing work motivation is an encouragement for employees to a good job and can provide good performance for the company.

Rivai (2011) states the process of work motivation is the willingness to use maximal the results of efforts in achieving company goals with the intention of satisfying some personal needs. The need must also be consistent and consistent with the objectives of the company. Fulfilling the needs of the less will create gap between employees, management, and top management.

In this research used indicator from research Tremblay et al. (2009) is intrinsic motivation as an activity for self-interest because everyone will find their own activities and satisfying for it. While extrinsic motivation is doing the activity because of an reason. There are various types of extrinsic motivations that can be controlled relative by external factors, such as self-regulation through the goals and values of the individuals obtained.

$\mathrm{H} 2$ : Work Motivation has a significant effect on Job Satisfaction.

Employee Engagement. An individual employee engagement, satisfaction, and enthusiasm for doing his job is a form of employee engagement (Robbins \& Judge, 2007). Can be interpreted that the employee engagement as a positive motivational developing by vigor, dedication, and absorption (Schaufeli, 2002). In an organization to develop and maintain engagement, a two-way relationship is required between management and employee, (Robinson et al., 2004). Schaufeli et al., (2002) explain that there are three dimensions of employee engagement, such as:

a) Vigor, characterized by high levels of energy and mental stamina at work, willingness to invest effort in work effort, diligent and strong..

b) Dedication, characterized by enthusiasm, inspiration, pride, and challenge. Dedication not only includes the cognitive dimension, but also the affective dimension

c) Absorption, characterized by a high concentration and great fun with the work, where time passes quickly and someone has difficulty separating from work.

In this study to measure the level of employee engagement used three dimensions employee engagement proposed by Schaufeli et al. (2002) namely dimensions Vigor, Dedication, and Absorption.

H3: Quality of Work Life has a significant effect on Employee Engagement.

$\mathrm{H} 4$ : Work Motivation has a significant effect on Employee Engagement.

Job Satisfaction. When individuals talk about employee attitudes, it means a job satisfaction. Job satisfaction is a positive feeling about a person work that is the result of a performance evaluation (Robbins \& Judge, 2007). With job satisfaction, an employee can feel his job is fun or not to work (Bangun, 2012). Many factors that affect employee job satisfaction, not only about salary, but there are factors related to the work itself, such as relationships with top management and employee, working conditions, and regulations.

In this study, the indicators and items to be used for measuring job satisfaction refer to research conducted by Closon et al. (2015) such as the work itself, the work environment, working relationships with colleagues, and supervision. The impact that will be seen if an employee is satisfied in working is more productive, have a high loyalty, and will be more involved in achieving company goals.

H5: Job Satisfaction has a significant effect on Employee Engagement.

H6: Quality of Work Life has a significant effect on Employee Engagement through Job Satisfaction as an intervening variable.

H7: Work Motivation has a significant effect on Employee engagement through Job Satisfaction as an intervening variable.

\section{METHODS OF RESEARCH}

The research method used in this study is explanatory research with quantitative approach. Explanatory research is a research that intends to explain the position of the variables studied and the relationship between research variables (Sugiyono, 2012).

Location and sample. This research was conducted at the Merdeka University of Malang with the respondents are 74 lecturers. The questionnaires are distributed as much as 
74 questionnaires and then all the questionnaires are processed to get the results of the respondents' answers.

Measurement and research instruments. The independent variables used in this research is Quality of Work Life (QWL), where the variable measured using indicators developed by Lee et al. (2015), that is health \& safety needs, economic needs, selfactualization \& esteem needs and social \& knowledge needs. Next, Work Motivation variable measured using indicators developed by Tremblay et al. (2009) are intrinsic \& extrinsic motivation. The dependent variable in this research is Job Satisfaction variable which is measured by using indicators developed by Closon et al. (2015) that is work, work environment, relationship with colleague and supervision. While the intervening variable is employee engagement variable measured by using indicators developed by Schaufeli et al., (2002) that is vigor, dedication, and absorption. Each indicator is measured by the Likert scale of 1 (one) to 5 (five). 1 = strongly disagree, $2=$ disagree, $3=$ neutral, $4=$ agree and $5=$ strongly agree. This research using Path analysis to get the result of questionnaire processing.

The hypothesis in this research that is:

H1: Quality of Work Life has a significant effect on Job Satisfaction.

$\mathrm{H} 2$ : Work Motivation has a significant effect on Job Satisfaction.

H3: Quality of Work Life has a significant effect on Employee Engagement.

$\mathrm{H} 4$ : Work Motivation has a significant effect on Employee Engagement.

H5: Job Satisfaction has a significant effect on Employee Engagement.

H6: Quality of Work Life has a significant effect on Employee Engagement through Job Satisfaction as an intervening variable.

H7: Work Motivation has a significant effect on Employee Engagement through Job Satisfaction as an intervening variable.

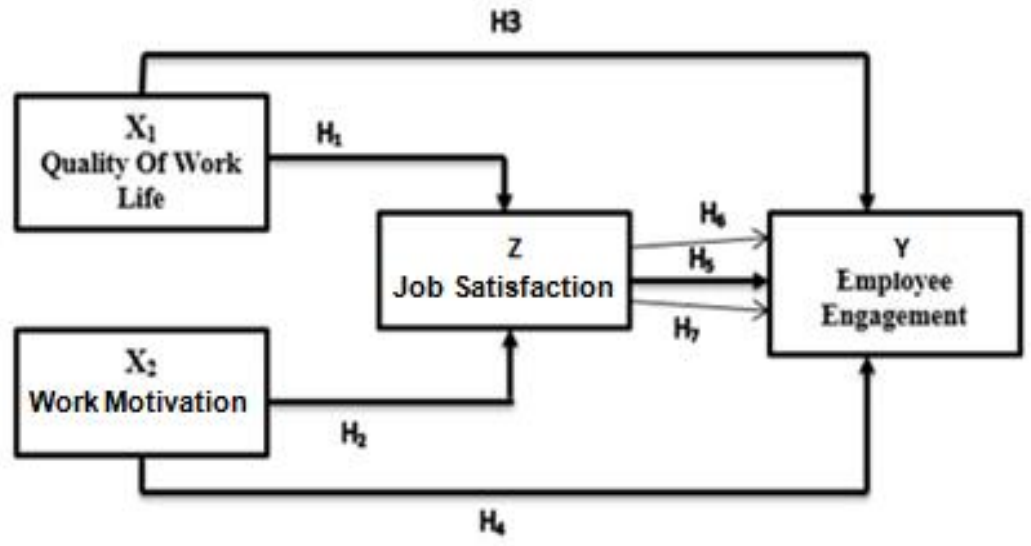

Figure 1 - Hypothesis models

\section{RESULTS AND DISCUSSION}

Based on survey results, the majority of respondents are female (54\%) with an average age of 39 to 49 years (35\%). Most respondents work experience was more than 20 to 24 years $(23 \%)$ and the level of education is the master program of 60 people $(81 \%)$. In accordance with the hypothesis that has been described, then this study using inferential statistical data analysis measured by using Path analysis.

Based on table 1, while the hypothesis of research is: hypothesis 1 which states Quality Of Work Life has a significant effect on Job Satisfaction, showing the beta coefficient of 0.544 with t-statistics of 6.041 and probability of $0.000(p<0.05)$, then the decision is Quality Of Work Life has a significant effect on Job Satisfaction accepted. The results of this study support previous research conducted by Lee et al. (2015). But, this study does not support research conducted by Arif \& llyas (2013) which states that quality of work life does not affect the commitment and engagement of employees. And also not support research 
conducted by Gunay and Boylu (2014) which shows some variable quality of working life has no significant effect on job satisfaction. If seen in practice at the University of Merdeka, Quality of work life in the University of Merdeka Malang can improve the dignity of employees through job satisfaction and humanize workers by providing a comfortable working environment, providing opportunities to grow, reward good lecturers, and make time for socializing.

Table 1 - Hypothesis Testing Result

\begin{tabular}{|c|c|c|c|c|c|}
\hline \multicolumn{2}{|c|}{ Hypothesis } & $\begin{array}{c}\text { Standardized } \\
\text { Coefficients (Beta) }\end{array}$ & T-statistics & Sig. & Conclusion \\
\hline H1 & Quality of Work life $\rightarrow$ Job satisfaction & 0.544 & 6.041 & 0.000 & significant \\
\hline H2 & Work Motivation $\rightarrow$ Job Satisfaction & 0.372 & 4,137 & 0.000 & significant \\
\hline H3 & $\begin{array}{c}\text { Quality of Work life } \rightarrow \text { Employee } \\
\text { Engagement }\end{array}$ & 0.214 & 2.005 & 0.049 & significant \\
\hline H4 & Work Motivation $\rightarrow$ Employee engagement & 0.221 & 2.285 & 0.025 & significant \\
\hline H5 & Job Satisfaction $\rightarrow$ Employee engagement. & 0.496 & 4.337 & 0.000 & significant \\
\hline & Direct Effect & $\begin{array}{c}\text { Indirect } \\
\text { Effect }\end{array}$ & $\begin{array}{c}\text { Total } \\
\text { effect }\end{array}$ & \\
\hline H6 & $\begin{array}{c}\text { Quality of Work Life }(\mathrm{X} 1) \rightarrow \text { Job Satisfaction } \\
(\mathrm{Z}) \rightarrow \text { Employee engagement }(Y)\end{array}$ & 0.214 & 0.270 & 0.484 & significant \\
\hline H7 & $\begin{array}{c}\text { Work Motivation }(\mathrm{X} 2) \rightarrow \text { Job Satisfaction }(\mathrm{Z}) \\
\rightarrow \text { Employee engagement }(\mathrm{Y})\end{array}$ & 0.221 & 0.185 & 0.406 & significant \\
\hline
\end{tabular}

Source: Data that have been processed by using Path Analysis.

Hypothesis 2 which states Work Motivation has a significant effect on Job satisfaction, showing the beta coefficient of 0.372 with t-statistics 4,137 and probability $0.000(p<0,05)$, then the decision that Work Motivation has a significant effect on Job satisfaction is accepted. The results of this study support previous research conducted by Hayati and Caniago (2012) which shows that the motivation of work directly affects job satisfaction. Robbins and Judge (2007) state that Motivation as a process that explains the intensity, direction, and perseverance of efforts to achieve a goal. In this study, University of Merdeka is considered capable of providing a sense of security in the sustainability of work, such as long service guarantee so that it can motivate the lecturers.

Hypothesis 3 which states Quality Of Work Life has significant effect to Employee Engagement, showing the beta coefficient of 0.214 with t-statistics equal to 2.005 and probability equal to $0.049(p<0.05)$, then the decision of Quality Of Work Life has significant influence to Employee Engagement is accepted. The results of this study support previous research conducted by Kanten \& Sadullah (2012) which shows that quality of work life has a direct and significant effect on employee engagement. The relationship of quality of work life with employee engagement can be reinforced by the social exchange theory proposed by Thibault and Kelley in Bungin (2008). This theory suggests that one's contribution in a relationship, in which the relationship can affect the contribution of others.

In the next hypothesis, Work Motivation has a significant effect on Employee Engagement, which is shown by the beta coefficient of 0.221 with t-statistics of 2.285 and probability of $0.025(p<0.05)$, then the decision is hypothesis 4 is accepted. The results of this study support previous research conducted by Mehrzi \& Singh (2016) which showed that the motivation of employees also affects employee engagement. The study was conducted at the University of Abu Dhabi. In this research lecturer at the Merdeka University of Malang has high work motivation. Giving intrinsic and extrinsic motivation is necessary to keep in mind in order to create a moral so that it will affect the involvement of lecturers at the Merdeka University of Malang.

The result of testing of Job Satisfaction on Employee Engagement a beta coefficient value of 0.496 with t-statistics of 4.337 and probability of $0.000(p<0,05)$, stated that hypothesis 5 is accepted. This study supports previous research conducted by Bailey et al. (2016) which shows that job satisfaction affects directly to employee engagement. Macey and Schneider (2008) identified two components of employee engagement namely, the 
involvement of feelings (focus and enthusiasm). In this study found that lecturers of the Merdeka University of Malang have the considerable energy to work. In addition, the lecturers also feel very challenged with the work provided. When a lecturer is engaged with work, it will affect his psychological characters, such as confidence and optimism. This can encourage lecturers to work even further and will encourage satisfaction and impact on high commitment.

So it is with hypothesis 6 and hypothesis 7 is accepted. In hypothesis 6 that indirect effect of Quality of Work Life variable to Employee Engagement through Job Satisfaction equal to 0.270 , so the total effect of Job Satisfaction to Employee Engagement equal to 0,484 . Hypothesis test results obtained $Z$ value of 2.035. The value of $Z$ statistics 2.035> 1.96 so there is indirect effect Quality Of Work Life on Employee Engagement through Job Satisfaction significantly. The results of this study do not support research conducted by Arif and llyas (2013) which states that the quality of work life has an effect on job satisfaction, but has no impact on employee engagement.

In hypothesis 7 that indirect effect of Work Motivation variable to Employee Engagement through Job Satisfaction equal to 0.185 , so the total effect of Job Satisfaction to Employee Engagement equal to 0.406. It shows that Job Motivation variable gives the highest effect on Employee Engagement. The result of hypothesis testing gets $Z$ value of 1.988. The value of $Z$ statistics $1.988>1.96$ so that $\mathrm{H} 0$ rejected which means that there is indirect effect Motivation Work on Employee Engagement through Job Satisfaction significantly. The results of this study support previous research conducted by Hayati and Caniago (2012). Lecturers of the University of Merdeka Malang who have high work motivation and job satisfaction can form a situation that makes themselves feel engaged at the university. Lecturers who are engaged will have a high commitment also to where they work. Therefore, the provision of motivation to the lecturers is very important in order to improve job satisfaction and employee engagement.

\section{CONCLUSION}

Quality of Work Life which is a condition as a result of interaction between individual and work in an institution will create a situation where if the interaction is good, it will affect work motivation and job satisfaction and create employee engagement. In this research, there are suggestions and limitations of research that is expected by the Merdeka University of Malang to maintain and improve the service to Job Motivation, because Job Motivation variables have a significant influence on Employee Engagement through Job Satisfaction so that Employee Engagement will get better. Given the many other variables that are not included in this study, it is expected to further researchers to add related variables so as to refine the previous research.

\section{REFERENCES}

1. Amstrong, M. (2010). Armstrong's Essential Human Resource Management Practice. United States: Kogan Pages.

2. Anitha, J. (2014). Determinants of employee engagement and their impact on employee performance. International Journal of Productivity and Performance Management. Emerald Group Publishing Limited, 63 (3), 308-323.

3. Arif, S., \& Maryam, I. (2013). Quality of work-life model for teachers of private universities in Pakistan. Journal of Quality Assurance in education. Emerald Group Publishing Limited, 21 (3), 282-298.

4. Bailey, A. A., \& Al-Meshal, S. (2016). The roles of employee job satisfaction and organizational commitment in the internal marketing-employee bank identification relationship. International Journal of Bank Marketing. Emerald Group Publishing Limited, 34 (6), 821-840.

5. Bangun, W. (2012). Manajemen Sumber Daya Manusia. Jakarta: PT. Gelora Aksara Pratama. 
6. Bungin, B. (2008). Sosiologi Komunikasi. Jakarta: Kencana.

7. Cascio, W. F. (2006). Managing human resources: Productivity, Quality of Work Life and Profits. 7th Edition Burr Ridge: Irwin McGraw-Hill.

8. Closon, C., Leys, C., \& Hellemans, C. (2015). Perceptions of corporate social responsibility, organizational commitment and job satisfaction. Management Research: The Journal of the Iberoamerican Academy of Management. Emerald Group Publishing Limited, 13 (1), 31-54.

9. Günay, G. \& Boylu, A. A. (2014). Moderator Effects Of Quality Of Life On Job Satisfication Of The Academic Staff In University. International Journal of Arts \& Sciences, 7 (6), 659-669.

10. Hayati, K., \& Caniago, I. (2012). Islamic Work Ethic: The Role of Intrinsic Motivation, Job Satisfaction, Organizational Commitment and Job Performance. International Congress on Interdisciplinary Business and Social Science, 65, 272-277. DOI: 10.1016/j.sbspro.2014. 05.148

11. Ivancevich, J. M. (2010). Human Resources Management. Singapore: Mc Graw Hill.

12. Kanten, S., \& Sadullah, O. (2012). An empirical research on relationship quality of work life and work engagement. Journal of Social and Behavioral Sciences, 62, 360-366. DOI: 10.1016/j.sbspro.2012.09.057

13. Lee, J-S., Back, K-J., \& Chan, E. S. W. (2015). Quality of work life and job satisfaction among frontline hotel employees $A$ self-determination and need satisfaction theory approach. International Journal Of Contemporary Hospitality, 27 (5), 768-789.

14. Macey, W. H. \& Schneider, B. (2008). The Meaning of Employee Engagement. Industrial and Organizational Psychology, 1 (1), 3-30.

15. Mehrzi, N., \& Singh, S. K. (2016). Competing through employee engagement: a proposed framework. International Journal of Productivity and Performance Management, 65 (6), 831-843.

16. Nawawi, H. (2001). Manajemen Sumber Daya Manusia Untuk Bisnis dan Kompetitif. Yogyakarta: Gajah Mada University Press.

17. Park, J. \& Gursoy, D. (2012). Generation Effects on Work Engagement among US Hotel Employees. Internation Journal of Hospitality Mangement, 31 (4), 1195-1202. DOI: 10.1016/j.ijhm.2012.02.007

18. Rivai, V. (2011). Manajemen Sumber Daya Manusia untuk Perusahaan dari Teori ke Praktik. Jakarta: PT. Rajagrafindo Persada.

19. Robbbins, S.P. \& Judge, T.A. (2007). Perilaku Organisasi, Buku 1 dan 2. Jakarta: Salemba Empat

20. Robinson, D., Perryman, S., \& Hayday, S. (2004). The drives of employee engagement. (IES PDF Report). UK: Institute for Employment Studies.

21. Schaufeli, W.B., Salanova, M., Roma, V.G., \& Bakker, A.B. (2002). The measurement of engagement and burnout: A two sample confirmatory factor analityc approach. Journal of Happiness Studies, 3, 71-92.

22. Siagian, S.P. (2004). Teori Pengembangan Organisasi. Bumi Aksara. Jakarta: Bumi Aksara. Jakarta.

23. Stone, R. (2005). Human Resource Management, Fifth Edition. John Wiley \& Sons Australia, Ltd 42 McDougall Street, Milton. Australia.

24. Sugiyono. (2012). Metode Penelitian Kuantitatif Kualitatif dan R\&D. Bandung: C.V Alfabeta.

25. Tremblay, M. A., Blanchard, C. M., Taylor, S., Pelletier, L. G., \& Villeneuve, M. (2009). Work Extrinsic and Intrinsic Motivation Scale: Its Value for Organizational Psychology Research, Canadian Journal of Behavioural Science, 41 (4), 213-226. 